\title{
The Interplay between Digital Competencies and Information Literacy in Academic Writing Online Class during COVID-19 Pandemic (PLS-SEM Approach)
}

\author{
Lastika Ary Prihandoko \\ Universitas Musamus, Indonesia \\ Email: prihandoko@unmus.ac.id
}

Submitted: 09/01/2021

Revised: 21/01/2021

Accepted: 27/01/2021

\section{E-ISSN : $2579-4574$}

P-ISSN : 2549-7359

\begin{abstract}
Due to insufficient academic literacy competency, which consists of information literacy and digital competency, students face online learning barriers during the COVID-19 pandemic. In addition, in the 21st-century learning framework, digital competency has considered as an essential skill. This study examines the interplay between mastery of hardware \& software, digital cooperation, digital security, mastery of digital development, and digital skills toward information literacy. They were randomly selected as respondents was a sample of 258 students from the ESP class who took academic writing in Papua's university. The data was analyzed using Smart PLS 3.0.0. in order to conduct exploratory factor analysis. The results show that digital competency correlates positively with digital cooperation, digital security, and digital development mastery. Meanwhile, hardware and software mastery have a positive association with digital cooperation. In addition, digital competency has positive correlation toward information literacy. The implications for academic staff and policymakers of the findings of this study are presented.
\end{abstract}

Keywords: Exploratory Factor Analysis, Digital Competency, Information Literacy, Academic Writing, COVID-19

\section{https://ojs.unm.ac.id/eralingua}

This work is licensed under a Creative Commons Attribution-NonCommercial 4.0 International License 


\section{INTRODUCTION}

The COVID-19 pandemic has had a significant effect on almost all world sectors, mainly the educational sectors. Indonesia's COVID-19 cases have been massively increased, so the government has taken several steps to reduce the spread of this virus as a reaction to this pandemic by enacting physical and largescale social restrictions. In addition, some cities have issued a decree concerning the closing of public facilities. In response to the COVID-19 pandemic, Papua, as the easternmost province in Indonesia, also implemented a local lockdown to initiate university closures. This policy then triggers the change of traditional learning to online learning. There is also a transformation of academic writing courses, which means that students must be able to carry out online classes.

Digital competency and information literacy are considered essential skills in delivering online lectures while carrying out online courses. Furthermore, information literacy is crucial concerning academic literacy, including academic writing skills within it (Bury, 2016). Improving student information literacy through learning is not a single circumstance, as many factors influence this ability's indicators. Competency problems in information literacy are experienced by domestic students and the international students encounter the same problems (Wingate \& Tribble, 2012). Gender, culture, and educational background are very closely related to students' ability to read academic texts and the ability to practice writing (Lillis, 2002). In addition, previous research that identified that gender has a role in the capacity for information literacy expressed the same view (Gravill et al., 2006; Hohlfeld et al., 2013; Nahyun \& Hana, 2017). However, research results also underline that data literacy is independent without gender influence (Mahmood, 2013; Tsai \& Tsai, 2010; Yi, 2007). It is not possible to generalize previous studies related to gender and information literacy's capacity to a broader scope related to student academic life.

Students' success in the academic context is inseparable from the students' academic abilities. In particular, in the form of undergraduate thesis writing requiring functional academic literacy skills, upper-semester students are expected to complete the final project. Most students, however, have barriers to finding material for writing a thesis (Hyland \& Shaw, 2016), which makes the writing process demand a long time, and it is hard to do (Paltridge \& Starfield, 2013). Previous research has shown that students have barriers to information literacy, which involves finding, evaluating and using different information sources (Berzonsky \& Richardson, 2008; Chowdhury et al., 2011; Dubicki, 2010). Lack of adequate information literacy skills will lead to severe problems facing students in the form of delays in graduation to the threat of dropouts.

The level of various competencies in information literacy among students correlates with the writing skills of students. Students will avoid reliance on low reference sources from internet searches with appropriate information literacy skills (Williams et al., 2008) because they can identify quality articles that are relevant to student projects (Berzonsky \& Richardson, 2008) that are justified based on the ability to think critically (Scott \& Simmons, 2006). Not all students, however, have sufficient competence in information literacy to support students' academic lives. 
MacMillan and MacKenzie (2012) found that students suffer from low information literacy and academic literacy because they have barriers to finding the correct article, reading, and using it on students' academic goals. Furthermore, the limited quality and relevant articles mostly presented in English make students more frustrated, particularly in the undergraduate thesis's writing activities.

To be mastered by students through independent learning or university intervention, information literacy's capacity is crucial. The university should be a pioneer in improving competency in information literacy with the long-term objective of having autonomous students when dealing with all projects requiring sound and quality information sources (Shenton \& Fitzgibbons, 2010). In a broader range of academic literacy, the capacity for information literacy is a joint responsibility (Beard \& Dale, 2010). It requires a harmonious synchronization between librarians and student academic life (Broady-Preston et al., 2012). The librarians' responsibility is to get out of their comfort zones to work with students in different disciplines (Lahlafi et al., 2012). Gunn et al. (2011) added that the collaboration between the academic community consisting of librarians, staff, and academics creates academic ability. Students need strong support from academia, where students carry out their studies, to become the main players in acquiring information literacy skills.

Special attention has been drawn from previous studies to the importance of information literacy for students to succeed in their academic lives. Broady-Preston et al. (2012) describe students' conduct and perceptions who focus on information literacy in history in the global sphere. Active learning by module-supported students can also enhance international students' information literacy and academic abilities (Lahlafi et al., 2012). In addition, belief insignificance and self-efficacy are essential parts of information literacy's core capabilities (Pinto, 2016). The context of academic literacy, which lacked support from universities through ICT participation and information literacy, was discovered by (Guzmán-Simón et al., 2017). Meanwhile, Akayoglu et al. (2020) found that the level of digital literacy abilities is affected by teaching staff and social media as learning media. Generally, prior research suggested that the ability to equip students with information literacy was affected by students' internal and external factors. This research seeks to elaborate the research by examining the relationship between digital competency and information literacy and the interplay within digital competency.

To date, research related to information literacy in Indonesia, based on the regional context, is limited to the use of several experiments to improve information literacy capabilities (Hasanah \& Rachman, 2019), cross-sector involvement in improving information literacy capabilities (Fairuz et al., 2019), and the level of capacity of lecturers in digital information literacy (Berutu et al., 2019; Fuad \& Hamid, 2019). Also, previous research tends to be uninvestigated in the Indonesian region, particularly in the east, which has socio-demographic conditions that are different from the western regions. This study seeks to elaborate on data literacy research by offering different perspectives. This study attempts to test the hypothesis of whether digital competency is linked to information literacy used during the COVID-19 epidemic period in online learning. In the context of 
exploratory factor analysis, this study uses the PLS-SEM approach. Further follow-up for academic staff and higher education policymakers, particularly in rural areas such as eastern Indonesia, will be developed based on the findings. This new study is intended to frame students' academic literacy in terms of exploring the association between information literacy and digital skills and the interplay of digital skills. With the data obtained from this study, this information is expected to provide the basis for a more efficient policy to improve students' competency of information literacy.

Information literacy has a key role in making students successful in the academic world. Self-efficacy, motivation and information literacy are three main components of student academic development (Ross et al., 2013). These three components also affect students' abilities and preferences in choosing learning resources (Printo \& Pascual, 2017). Students need the ability to search for data to effectively communicate that information to the organization of information through analysis (Guzmán-Simón et al., 2017). Also, if accompanied by decent digital skills, this ability is the most representative ability in the academic world (Goodfellow, 2011).

Digital competence also plays an important role in shaping academic literacy in support of academic literacy competencies, in addition to information literacy competencies. Digital competency is interpreted into digital literacy by people and vice versa. While both have very distinct meanings. Digital competence first gained popularity around 2010 (Machin-Mastromatteo, 2012) before digital literacy became popular. In using IT, digital competence is defined as creativity, which helps acquire and update the skills required. Digital competence is used as a tool to turn its citizens into digital citizens who need information mastery to produce content and problem-solving skills without forgetting the security component (Janssen et al., 2013).

Digital competence, which is the capacity for digital literacy, is a compulsory requirement in the field of work due to the need to learn the skills used in this field (Ala-Mutka, 2011). Meanwhile, digital competence also requires the ability to interact with digital citizenship (Van Deursen \& van Dijk, 2009). Meanwhile, digital skills are also cognitive skills that include the use of digital devices for specific purposes following practical needs (Sicilia et al., 2018). For students, mastering digital competency is necessary because it will be used in an academic context and be used by students in their future professional careers.

Digital competency mastery and information literacy are becoming part of digital literacy. Tuamsuk and Subramaniam (2017) emphasize that digital literacy skills, technical, cognitive, and emotional-social skills play a key role in the creation of digital literacy skills. Digital literacy, on the other hand, requires ICT and internet mastery in order to receive, regulate, integrate and communicate the information obtained in order to play a role in the knowledge society (Parvathamma \& Pattar, 2013). For students in the academic world, digital literacy is a key component. Students are required to have the skills to survive in an era dominated by digital information and communication (Littlejohn et al., 2012). 
The ability to use an online information search strategy (OISS) is required to implement digital literacy capabilities to obtain information, particularly from the internet. OISS is a skill which students must possess. The main concept that needs to emerge when talking about OISS is the interaction of different search systems to use various popular information search engines (Kurt \& Emiroglu, 2018). OISS requires digital literacy capabilities in which students can manage, evaluate and reliably access the information they access from the website (Istance \& Kools, 2013). On the other hand, OISS cannot stand alone because it is closely linked to students with high self-efficacy levels on the internet. Students with high self-efficacy levels have better information and have learned better than those with low internet selfefficacy, even proven (Tsai \& Tsai, 2010). Cognitive absorption will be influenced by students who frequently interact with technology. The better the critical analysis it has, the more it will continue to be inspired to look for more data.

In addition to being linked to students' self-efficacy, OISS is also closely linked to digital literacy. In information search skills, digital literacy is an important factor in (Lea, 2013). People with a high capacity for digital literacy will be able to give their arguments accurately and well and can easily find and determine the information they want (Lea \& Jones, 2011). The type of information students commonly look after is another factor that also determines online searching strategies. Students who are used to accessing information about everyday life will be better able to obtain information than those who only focus on learning activities (Atoy Jr et al., 2020).

Studies related to information literacy, particularly in Indonesia itself, are not limited to the global sphere. Several studies related to information literacy have been carried out. Hasanah and Rachman (2019) underlined the important role of librarians' skills in meeting users' needs for information literacy. Integrated science learning materials among senior high school students can enhance critical thinking abilities and information literacy (Fairuz et al., 2019). On the other hand, through libraries and digital information sources, Berutu et al. (2019) enhance information literacy capacity. Furthermore, Fuad and Hamid (2019) found that lecturers' capacity for digital information literacy was moderate. This latest research is designed to use the PLS-SEM approach to develop knowledge. It is hoped that by using the PLS-SEM approach, it can provide new insights whose findings can be used by academic staff and policy makers specifically in Indonesia as well as become global academic reference information. In addition, the following are the hypotheses used to see the information literacy and digital competency skills of the students using the theoretical framework of information literacy and digital competency, which are formed by several accompanying skills.

1. Hypothesis ( $\left.\mathrm{H}_{1}\right)$ Digital Cooperation is positively related to Digital Competency.

2. Hypothesis $\left(\mathrm{H}_{2}\right)$ Hardware Mastery $\left(\mathrm{H}_{2} \mathrm{a}\right)$ and Software Mastery $\left(\mathrm{H}_{2} \mathrm{~b}\right)$ are positively related to Digital Cooperation.

3. Hypothesis ( $\left.\mathrm{H}_{3}\right)$ Digital Security is positively related to Digital Competency.

4. Hypothesis $\left(\mathrm{H}_{4}\right)$ Digital Development is positively related to Digital Competency.

5. Hypothesis ( $\left.\mathrm{H}_{5}\right)$ Digital Competency is positively related to Information Literacy 
The conceptual framework for the hypothesis to be tested can be seen in Figure 1

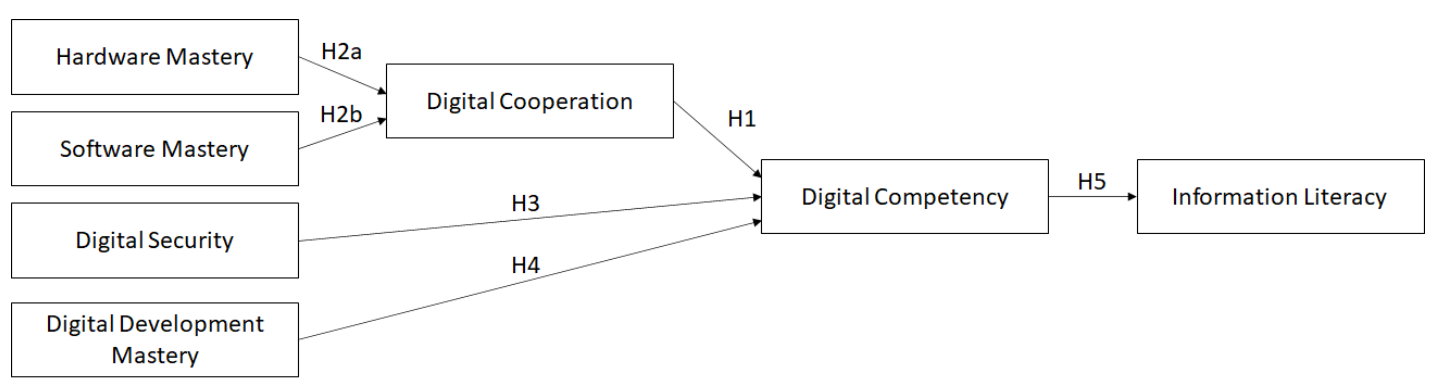

Figure 1. The conceptual framework of the hypotheses

\section{RESEARCH METHOD}

This study is a quantitative study aimed at exploring the link between digital competency, digital collaboration, digital security, mastery of digital development, and software and hardware mastery. Respondents derived from students at one of Papua's tertiary institutions in the engineering faculty. A simple random sampling of data obtained through online questionnaires using Google Form. The questionnaire link is distributed to learners through the WhatsApp group, and the questionnaire filling time is done on September 2-16, 2020, in two weeks. A total of 258 responses have been collected based on the online questionnaire, which has been distributed.

Twenty-two questions with 5-likert scale were adapted from several previous studies (Atoy Jr et al., 2020; lordache et al., 2017; Motyl et al., 2017). The questionnaire measures the students' perception with several indicators: hardwaresoftware mastery, digital development mastery, digital security-cooperation, digital competency, and information literacy. The questionnaire also contains demographic information from students in gender, ethnicity, and student-owned device. The researcher tried to avoid misinterpretation by respondents by translated the instrument into Bahasa Indonesia. Two experts from the technology information discipline were validated the instrument's content and three experts from Bahasa Indonesia have inspected grammatical error and clarity assessment. Later, researchers conducted pilot tests for 60 respondents. The statistical analysis process is carried out using SPSS 23 to measure the instrument's reliability and validity. The Alpha Cronbach value is 0.823 based on measurements, and the r-value was between 0.61 and 0.83 with an $r$ table of 0.138 . Therefore, a good degree represents the value of reliability, and the value of validity indicates that each item is classified as valid.

Three stages of data analysis were performed using PLS-SEM (Hair Jr et al., 2014) to analyze the data obtained. The first stage is the specification phase of the measurement model, which includes describing the exogenous and endogenous constructs' models, constructing the inner \& outer model, and determining the reflective/formative model. The second stage is the external model assessment phase, which includes evaluating composite reliability, evaluating convergent validity, and evaluating discrimination validity. In the reflective model analysis 
phase, the last phase is the internal model evaluation, which consists of the determination coefficient, cross-validated redundancy, examination of path coefficient/hypotheses, and effect size determination.

\section{RESULT AND DISCUSSION}

The specification model is the first stage of the PLS-SEM approach. This study's model specification is shown in Figure 2. Hardware Mastery (HM), Software Mastery (SM), Digital Security (DS) and Digital Development Mastery are part of the exogenous model (DD). Digital cooperation (DCo) and digital competency are the exogenous models that doubles as an endogenous model (DC). An endogenous model is Construct Information Literacy (IL). With 7 inner models and 25 outer models, the specification model has been defined. As a reflective model, the model is categorized.

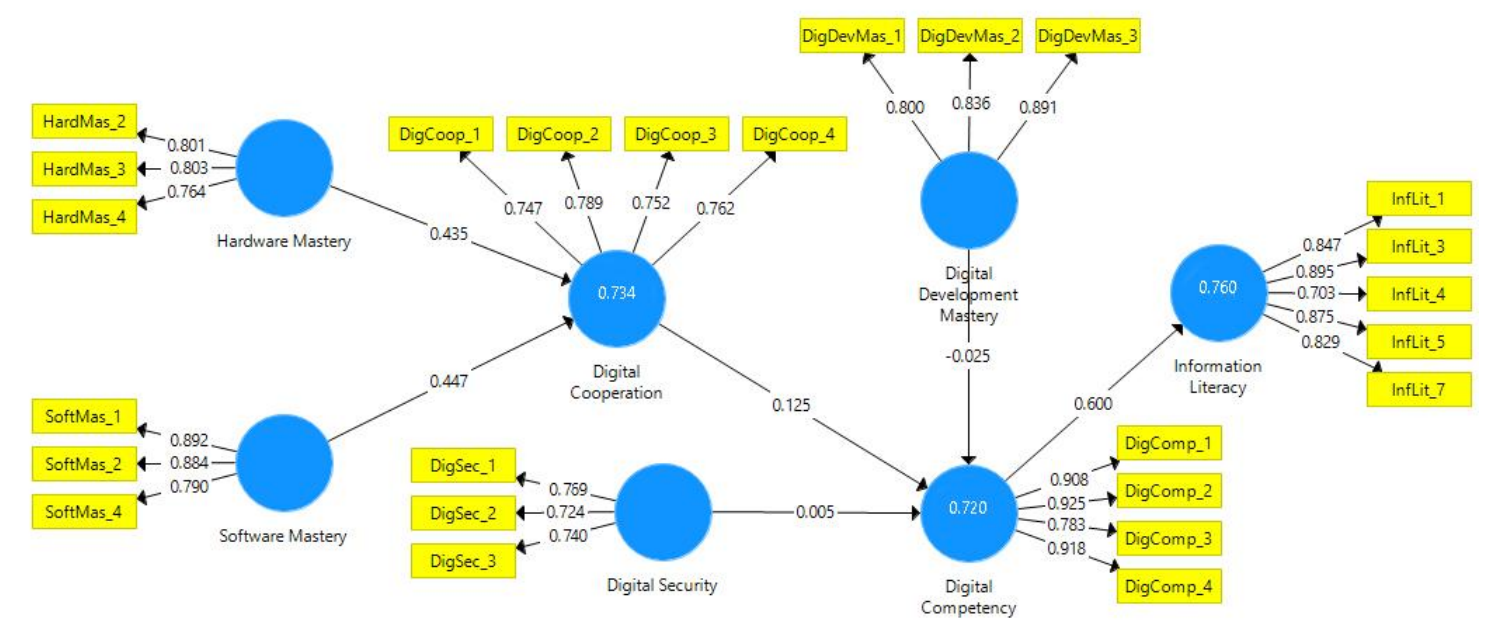

Figure 2. Confirmatory Factor Analysis

Table 1. Cronbach's Alpha, composite reliability, and AVE

\begin{tabular}{lcccc}
\hline & $\begin{array}{c}\text { Cronbach's } \\
\text { Alpha }\end{array}$ & rho_A & $\begin{array}{c}\text { Composite } \\
\text { Reliability }\end{array}$ & $\begin{array}{c}\text { Average } \\
\text { Variance } \\
\text { Extracted } \\
\text { (AVE) }\end{array}$ \\
\hline DC & 0.857 & 0.758 & 0.765 & 0.721 \\
\hline DCO & 0.861 & 0.861 & 0.769 & 0.838 \\
\hline DD & 0.807 & 0.908 & 0.835 & 0.783 \\
\hline DS & 0.859 & 0.761 & 0.767 & 0.831 \\
\hline IL & 0.835 & 0.702 & 0.849 & 0.756 \\
\hline SM & 0.863 & 0.802 & 0.768 & 0.792 \\
\hline
\end{tabular}

The outer model evaluation is the second phase. The researcher analyzed to evaluate the relationship between variables and the indicators contained, this analysis step is used to evaluate the model. The first step in the evaluation of the 
outer model is to evaluate the composite reliability, which consists of evaluating the reliability of the inner consistency and the reliability of the indicator. The recommended value ranges from .70 to .90 when evaluating internal consistency reliability (Hair et al., 2019). The composite reliability value from the analysis results in Table 1 is a value of 0.765 to 0.865 , which is categorized as satisfactory reliability. In addition, the analysis is carried out to determine the reliability indicator. The value to which the indicator belongs should be> 7088 (Hair Jr et al., 2014). Figure 2 shows that because it has a value of $<7.08$, namely HardMas 1 ( 0.636 ), SoftMas 3 (0.678), InfLit 2 (0.686) and InfLit 66, there are 4 dropping indicators (0.603). Moreover, there are at least 3 indicators in each variable to establish the reliability indicator.

Evaluating convergent validity and discriminant validity is the next step in conducting an external model assessment. The Average Variance Extracted (AVE) value should be greater than .050 . The obtained AVE values ranged from 0.721 to 0.838 , based on Table 1 . Thus, it establishes a convergent validity. On the other hand, the parameter used to evaluate discriminant validity is to evaluate the Heterotrait-monotrait Ratio (HTMT) number to ensure that each construct is different from other constructs. $<.85$ is the recommended number. There is no value higher than .85 based on the value obtained in the data analysis in Table 2 , which means that discriminant validity is established.

Table 2. Heterotrait-Monotrait Ratio (HTMT)

\begin{tabular}{lccccccc}
\hline & DC & DCO & DD & DS & HM & IL & SM \\
\hline DC & & & & & & & \\
\hline Dco & 0.711 & & & & & & \\
\hline DD & 0.695 & 0.679 & & & & & \\
\hline DS & 0.714 & 0.668 & 0.444 & & & & \\
\hline HM & 0.712 & 0.692 & 0.802 & 0.794 & & & \\
\hline IL & 0.754 & 0.744 & 0.711 & 0.139 & 0.619 & & \\
\hline SM & 0.728 & 0.717 & 0.663 & 0.717 & 0.808 & 0.721 & \\
\hline
\end{tabular}

The inner model assessment is the third phase. It is used in this stage to evaluate the structural model that reflects the relationship between variables and test the hypothesis in the internal model. To obtain a Variance Inflation Factor (VIF) value, researchers perform a collinearity test to ensure that no predictive problems arise due to high colinearity. The VIF recommended is $<3$. The obtained VIF values are in the range of 1,000 to 2,065 in Table 3 . There is no collinearity problem, so it is possible to continue the internal model evaluation analysis phase. 
Table 3. Colliearity Statistic (VIF)

\begin{tabular}{|c|c|c|c|c|c|c|c|}
\hline & DC & Dco & DD & DS & HM & IL & SM \\
\hline $\mathrm{DC}$ & & & & & & 1.000 & \\
\hline Dco & 2.065 & & & & & & \\
\hline DD & 1.502 & & & & & & \\
\hline DS & 1.542 & & & & & & \\
\hline $\mathrm{HM}$ & & 1.161 & & & & & \\
\hline \multicolumn{8}{|l|}{ IL } \\
\hline$S M$ & & 1.161 & & & & & \\
\hline
\end{tabular}

Evaluating coefficient determination is the first step in inner model evaluation. This step is used to evaluate the predictive precision of the model. The R2 value varied from 0 to 1 in three categories: .75, .50, .25 (large, moderate, substantial) (Hair Jr et al., 2014). The predictive accuracy value in Table 4 indicates that there is moderate predictive accuracy for digital competency and digital cooperation. The predictive accuracy value of information literacy, meanwhile, is great.

Table 4. R-Square $\left(R^{2}\right)$ Value

\begin{tabular}{lr}
\hline & R Square \\
\hline Digital Competency & 0.72 \\
\hline Digital Cooperation & 0.734 \\
\hline Information Literacy & 0.51 \\
\hline
\end{tabular}

Also, a cross-validated redundancy assessment will be carried out. The outcome of this assessment is to evaluate the predictive relevance of the inner model by calculating the value of Q2. The Q2 value, categorized into small (0.), medium (0.25) and substantial (0.50), should be greater than zero (Hair Jr et al., 2014). The values indicate, based on Table 5., that the predictive relevance model (Q2) has a substantial value (>0.50).

Table 5. Predictive Relevance $\left(Q^{2}\right)$

\begin{tabular}{|c|c|c|c|}
\hline & SSO & SSE & $\mathrm{Q}^{2}(=1-\mathrm{SSE} / \mathrm{SSO})$ \\
\hline DC & 712 & 264.552 & 0.511 \\
\hline Dco & 720 & 269.525 & 0.563 \\
\hline IL & 702 & 266.32 & 0.532 \\
\hline
\end{tabular}

The third step in the inner model evaluation is the evaluation of the path coefficients. The formulated hypothesis is analyzed at this stage. The standardized value of the path coefficient is between -1 (strong negative relationship) and +1 (strong positive relationship) (Hair Jr et al., 2014). Prior to determining significance, researchers determine standard errors (Helm et al., 2010). Based on Table 6, the standard error value obtained is $>.1$, which means the model has standard errors of 5 per cent. The standard error significance value of 5 per cent is used with T- 
Statistics (Wong, 2013). The T-Statistic value> 1.96 indicates a strong positive relationship with the model. Table 3.6 shows that $\left(\mathrm{H}_{4}\right)$ is not supported because the value is below 1.96. The value of $\left(\mathrm{H}_{1}\right),\left(\mathrm{H}_{2}\right),\left(\mathrm{H}_{3}\right),\left(\mathrm{H}_{5}\right)$ is greater than 1.96, which means that the four hypotheses are supported. In summary, digital skills were strongly correlated with information literacy, digital development cooperation and digital security were significantly correlated with digital skills, and digital cooperation was significantly correlated with hardware and software mastery. After the researcher verifies the significance of the relationship, the relevance of the significant relationship $\mathrm{f}^{2}$ is evaluated. The $.02, .15$, and .35 values denote small, medium, and large effects. Table 7 shows that digital competency has a major impact on data literacy. Digital cooperation is greatly affected by hardware and software mastery. Digital cooperation and digital security have an impact on digital competence on a medium scale. The mastery of digital development, which has a positive correlation with digital skills, has little impact.

Table 6. Structural model assessment

\begin{tabular}{llllll}
\hline & $\begin{array}{l}\text { Original } \\
\text { Sample } \\
(\mathrm{O})\end{array}$ & $\begin{array}{l}\text { Sample } \\
\text { Mean } \\
(\mathrm{M})\end{array}$ & $\begin{array}{l}\text { Standard } \\
\text { Deviation } \\
(\mathrm{STDEV})\end{array}$ & $\begin{array}{l}\mathrm{T} \text { Statistics } \\
(\mid \mathrm{O} / \mathrm{STDEV})\end{array}$ & $\begin{array}{l}\mathrm{P} \\
\text { Values }\end{array}$ \\
\hline DC -> IL & 0.6 & 0.607 & 0.04 & 14.829 & 0 \\
\hline DCO -> DC & 0.125 & 0.066 & 0.115 & 18.297 & 0.037 \\
\hline DD -> DC & -0.025 & 0.032 & 0.075 & 1.111 & 0.042 \\
\hline DS -> DC & 0.005 & 0.012 & 0.08 & 3.236 & 0.002 \\
\hline HM - > DCO & 0.435 & 0.443 & 0.102 & 4.284 & 0 \\
\hline SM -> DCO & 0.447 & 0.246 & 0.374 & 2.247 & 0.025 \\
\hline
\end{tabular}

Table 7. Effect Size

\begin{tabular}{|c|c|c|c|c|c|c|c|}
\hline & DC & Dco & DD & DS & HM & IL & SM \\
\hline$D C$ & & & & & & 0.563 & \\
\hline Dco & 0.113 & & & & & & \\
\hline DD & 0.013 & & & & & & \\
\hline DS & 0.142 & & & & & & \\
\hline $\mathrm{HM}$ & & 0.351 & & & & & \\
\hline IL & & & & & & & \\
\hline$S M$ & & 0.369 & & & & & \\
\hline
\end{tabular}

This current study is intended to determine the association of information literacy with digital skills and evaluate the interplay of digital skills competencies. The findings indicate that digital competence is associated with information literacy. Digital competence has a 51 percent impact on information literacy (moderate predictive effect). This finding is in line with the previous finding that implies that digital skills development contributes to academic literacy skills (Lea \& Jones, 2011), where these skills require learners to adapt to the use of digital media that requires new pedagogical skills (Cope \& Kalantzis, 2000). Moreover, previous research 
suggests that students' digital competence levels are consistent with teaching staff's competence (Fuad \& Hamid, 2019). Furthermore, universities must promote the improvement of information literacy skills in the university context, and policies must be issued to present concepts and strategies to address the challenges that have increased over the last decade (Merchant, 2013).

The second hypothesis accepted in this study is hardware \& software mastery are related to digital cooperation. Mastery hardware \& software is indirectly related to digital competency. The results are closely linked to previous research, which showed that knowledge of the use of technology, such as computers, software and hardware, often shapes digital skills (Gunn et al., 2011). Hardware and software mastery are linked to learners' motivational aspect that contributes to ICT mastery (Guzmán-Simón et al., 2017). It is also suspected that the availability of digital mastering equipment and internet access facilities will affect respondents' level of digital competence.

In addition, digital competence is associated with digital cooperation and digital security. Digital cooperation and aspects of digital security are vital when it comes to affecting digital competence. With this ability, it is possible to perform more dynamically digital skills useful for exploring and dealing with new technologies (Morellato, 2014), which are useful for obtaining and re-creating information to generate new knowledge, particularly in academic contexts (Cazco et al., 2016). The learners' process of mastering hardware, software, and data security aspects is an obligation for educators and students to become independent learners in mastering digital capabilities. Meanwhile, the acquisition of digital skills is not limited to the university context, because the acquisition process is complex, involving different domains, such as academic and social domains, derived from the involvement of colleagues in the house (Guzmán-Simón et al., 2017; Meyers et al., 2013).

In addition to mastering hardware, software, and data security capabilities, digital competency requires the ability to work together digitally and follow technological developments as well. Ferrari et al. (2014) recognize that communication and collaboration in digital competency are vital components. Moreover, digitally collaborating has a close relationship with certain types of work and practical tasks in the workplace (Sicilia et al., 2018). Thus, there has been a global consensus that digital capacity development in workplaces comprising various sectors is essential (Benson et al., 2002). Universities should also pay attention not only to the hard aspects of students' abilities related to the technical knowledge they receive from their majors. Special attention needs to be paid to mastering digital competency that contributes to digital literacy capabilities with the ultimate goal of academic literacy competence. Digital competence should be the initial basis of learning because it is one of the key elements of higher education that contributes to developing students' skills for future professional careers (Printo \& Pascual, 2017).

Previous studies had implied the importance of information literacy and digital competency associated with academic writing. Information literacy has a pivotal role for students who will be used for information searching, which becomes 
a powerful tool for succeeding academic writing (Torras \& Saetre, 2016). Katz et al. (2010) also argue that the process of academic writing is partially required the adequate mastery of information literacy and digital competency. In academic writing, it is necessary to use scientific sources to support the author's claims and arguments. Information literacy is important to be mastered by students to be able to use the information obtained in an acceptable manner (Bowler et al., 2011). Digital competency are part of the mastery of reading skills, which act as academic success indicators (Shaw \& Pecorari, 2013). Moreover, learners will use the ability of reading for writing (RFW) to acquire the knowledge and skills required to write effectively (Hyland \& Shaw, 2016), mainly to be applied to undergraduate thesis writing to achieve academic goals. The digital competency hand in hand with information literacy shape in the framework of literacies (Machin-Mastromatteo, 2012) which become essential competence for $21^{\text {st }}$ century learning (Mishra \& Kereluik).

The purpose of this study is to conduct an initial exploration of the association between digital competency and information literacy of students, particularly in rural areas, namely Papua. This study has various limitations. The research is limited, focusing on initial research to illustrate the empirical circumstances of students in Papua. This study's results have broader implications, particularly for all higher education stakeholders, who are limited to government agencies and the private sector. Universities need to pay special attention to digital skills, including mastery of hardware and software, digital cooperation and digital security, contributing significantly to information literacy in these competencies. Improving the information literacy of students gives learners more opportunities to succeed in academic life. Further research is needed to find solutions to enhance students' digital competency based on work-field needs analysis and students' current condition. Research in the form of developing curriculum application learning models is needed to provide comprehensive action to improve students' digital skills, particularly in eastern Indonesia, which has distinct features from western Indonesia.

\section{CONCLUSION}

The findings imply, based on this study, that information literacy is strongly correlated with digital competence. The interplay within digital competence indicates that digital cooperation is associated with hardware and software mastery, which is highly associated with digital competency. Digital security, moreover, is highly correlated with digital competence. Digital cooperation, meanwhile, has a positive connection with digital competence, but the value is not very significant. Previous studies have pointed out the importance of information literacy and digital competency toward the academic writing process. Students who have adequate information literacy and digital competency will be able to find, manage, and communicate the resource taken as insightful content for their writing in the academic context. Highlighting the importance of digital competency and information literacy, students need to promote those competencies. In order to enhance students' digital competence, further policies should be undertaken to respond to these findings to improve students' success rate in academic life. 
Meanwhile, to reform the existing imbalances, further action through policy in the form of matriculation is advised. It is anticipated that increased digital competence will provide provisions for students' information literacy.

\section{REFERENCES}

Akayoglu, S., Satar, H. M., Dikilitas, K., Cirit, N. C., \& Korkmazgil, S. (2020). Digital literacy practices of Turkish pre-service EFL teachers. Australasian Journal of Educational Technology, 36(1), 85-97.

Ala-Mutka, K. (2011). Mapping digital competence: Towards a conceptual understanding. Sevilla: Institute for Prospective Technological Studies.

Atoy Jr, M. B., Garcia, F. R. O., Cadungog, R. R., Cua, J. D. O., Mangunay, S. C., \& de Guzman, A. B. (2020). Linking digital literacy and online information searching strategies of Philippine university students: The moderating role of mindfulness. Journal of Librarianship and Information Science, 0961000619898213.

Beard, J., \& Dale, P. (2010). Library design, learning spaces and academic literacy. New library world.

Benson, A. D., Johnson, S. D., \& Kuchinke, K. P. (2002). The use of technology in the digital workplace: A framework for human resource development. Advances in Developing Human Resources, 4(4), 392-404.

Berutu, N., Delita, F., Astuti, A. J. D., Novira, N., \& Wirda, M. A. (2019). The Strategy to Strengthen Information Literacy Based on Library and Digital Resources. 1st International Conference on Social Sciences and Interdisciplinary Studies (ICSSIS 2018),

Berzonsky, W. A., \& Richardson, K. D. (2008). Referencing science: Teaching undergraduates to identify, validate, and utilize peer-reviewed online literature. Journal of Natural Resources \& Life Sciences Education, 37(1), 8-13.

Bowler, M., MacMillan, M., \& Hoyer, J. (2011). Information is social: information literacy in context. Reference Services Review.

Broady-Preston, J., Tedd, L., \& Pinto, M. (2012). Information literacy perceptions and behaviour among history students. Aslib Proceedings,

Bury, S. (2016). Learning from faculty voices on information literacy. Reference Services Review.

Cazco, G. H. O., González, M. C., Abad, F. M., Altamirano, J. E. D., \& Mazón, M. E. S. (2016). Determining factors in acceptance of ICT by the university faculty in their teaching practice. Proceedings of the Fourth International Conference on Technological Ecosystems for Enhancing Multiculturality,

Chowdhury, S., Gibb, F., \& Landoni, M. (2011). Uncertainty in information seeking and retrieval: A study in an academic environment. Information Processing \& Management, 47(2), 157-175.

Cope, B., \& Kalantzis, M. (2000). Multiliteracies: Literacy learning and the design of social futures. Psychology Press.

Dubicki, E. (2010). Research behavior patterns of business students. Reference Services Review. 
Fairuz, T., Kaniawati, I., \& Sinaga, P. (2019). Enhancing critical thinking skills and information literacy of students through integrated science teaching materials. Journal of Physics: Conference Series,

Ferrari, A., Brečko, B. N., \& Punie, Y. (2014). DIGCOMP: A framework for developing and understanding digital competence in Europe. eLearning Papers(38), 1.

Fuad, A., \& Hamid, A. (2019). Digital Information Literacy Competency among Lecturers of Sultan Ageng Tirtayasa University in Supporting Research and Scientific Publication. International Conference on Democratisation in Southeast Asia (ICDeSA 2019),

Goodfellow, R. (2011). Literacy, literacies and the digital in higher education. Teaching in Higher Education, 16(1), 131-144.

Gravill, J. I., Compeau, D. R., \& Marcolin, B. L. (2006). Experience effects on the accuracy of self-assessed user competence. Information \& Management, 43(3), 378-394.

Gunn, C., Hearne, S., \& Sibthorpe, J. (2011). Right from the start: A rationale for embedding academic literacy skills in university courses. Journal of University Teaching \& Learning Practice, 8(1), 6.

Guzmán-Simón, F., García-Jiménez, E., \& López-Cobo, I. (2017). Undergraduate students' perspectives on digital competence and academic literacy in a Spanish University. Computers in Human Behavior, 74, 196-204.

Hair, J. F., Risher, J. J., Sarstedt, M., \& Ringle, C. M. (2019). When to use and how to report the results of PLS-SEM. European business review.

Hair Jr, J. F., Sarstedt, M., Hopkins, L., \& Kuppelwieser, V. G. (2014). Partial least squares structural equation modeling (PLS-SEM). European business review.

Hasanah, A., \& Rachman, M. A. (2019). Librarian's Information Literacy Skills to Fulfilling Library Users' Needs A Public Library in Bogor, Indonesia. Record and Library Journal, 5(1), 22-32.

Helm, S., Eggert, A., \& Garnefeld, I. (2010). Modeling the impact of corporate reputation on customer satisfaction and loyalty using partial least squares. In Handbook of partial least squares (pp. 515-534). Springer.

Hohlfeld, T. N., Ritzhaupt, A. D., \& Barron, A. E. (2013). Are gender differences in perceived and demonstrated technology literacy significant? It depends on the model. Educational Technology Research and Development, 61(4), 639663.

Hyland, K., \& Shaw, P. (2016). The Routledge handbook of English for academic purposes. Routledge.

lordache, C., Mariën, I., \& Baelden, D. (2017). Developing digital skills and competences: A quick-scan analysis of 13 digital literacy models. Italian Journal of Sociology of Education, 9(1).

Istance, D., \& Kools, M. (2013). OECD work on technology and education: Innovative learning environments as an integrating framework. European Journal of Education, 48(1), 43-57.

Janssen, J., Stoyanov, S., Ferrari, A., Punie, Y., Pannekeet, K., \& Sloep, P. (2013). Experts' views on digital competence: Commonalities and differences. Computers \& Education, 68, 473-481. 
Katz, I. R., Haras, C., \& Blaszczynski, C. (2010). Does business writing require information literacy? Business Communication Quarterly, 73(2), 135-149.

Kurt, A. A., \& Emiroglu, B. G. (2018). Analysis of Students' Online Information Searching Strategies, Exposure to Internet Information Pollution and Cognitive Absorption Levels Based on Various Variables. Malaysian Online Journal of Educational Technology, 6(1), 18-29.

Lahlafi, A. E., Rushton, D., \& Stretton, E. (2012). Active and reflective learning initiatives to improve web searching skills of business students. Journal of information literacy, 6(1), 35-49.

Lea, M. R. (2013). Reclaiming literacies: competing textual practices in a digital higher education. Teaching in Higher Education, 18(1), 106-118.

Lea, M. R., \& Jones, S. (2011). Digital literacies in higher education: exploring textual and technological practice. Studies in higher education, 36(4), 377-393.

Lillis, T. M. (2002). Student writing: Access, regulation, desire. Routledge.

Littlejohn, A., Beetham, H., \& McGill, L. (2012). Learning at the digital frontier: a review of digital literacies in theory and practice. Journal of computer assisted learning, 28(6), 547-556.

Machin-Mastromatteo, J. D. (2012). Participatory action research in the age of social media: Literacies, affinity spaces and learning. New library world.

MacMillan, M., \& MacKenzie, A. (2012). Strategies for integrating information literacy and academic literacy. Library Management.

Mahmood, K. (2013). Relationship of students' perceived information literacy skills with personal and academic variables. Libri, 63(3), 232-239.

Merchant, G. (2013). Virtual literacies: Interactive spaces for children and young people (Vol. 84). Routledge.

Meyers, E. M., Erickson, I., \& Small, R. V. (2013). Digital literacy and informal learning environments: an introduction. Learning, media and technology, 38(4), 355367.

Mishra, P., \& Kereluik, K. (2011). What 21st century learning? A review and a synthesis.

Morellato, M. (2014). Digital competence in tourism education: Cooperativeexperiential learning. Journal of Teaching in Travel \& Tourism, 14(2), 184-209.

Motyl, B., Baronio, G., Uberti, S., Speranza, D., \& Filippi, S. (2017). How will change the future engineers' skills in the Industry 4.0 framework? A questionnaire survey. Procedia Manufacturing, 11, 1501-1509.

Nahyun, K., \& Hana, S. (2017). Personality traits, gender, and information competency among college students. Malaysian Journal of Library \& Information Science, 16(1), 87-107.

Paltridge, B., \& Starfield, S. (2013). The handbook of English for specific purposes (Vol. 592). Wiley Online Library.

Parvathamma, N., \& Pattar, D. (2013). Digital literacy among student community in management institutes in Davanagere District, Karnataka State, India. Annals of Library and Information Studies (ALIS), 60(3), 159-166.

Pinto, M. (2016). Assessing disciplinary differences in faculty perceptions of information literacy competencies. Aslib journal of information management. 
Printo, M., \& Pascual, R. F. (2017). Exploring LIS students' beliefs in importance and self-efficacy of core information literacy competencies. College \& Research Libraries, 77(6), 703.

Ross, M., Perkins, H., \& Bodey, K. (2013). Information literacy self-efficacy: The effect of juggling work and study. Library \& Information Science Research, 35(4), 279-287.

Scott, L. K., \& Simmons, S. R. (2006). Incorporating primary literature in undergraduate crop science courses. Journal of Natural Resources \& Life Sciences Education, 35(1), 225-233.

Shaw, P., \& Pecorari, D. (2013). Source use in academic writing: An introduction to the special issue. Journal of English for Academic Purposes, 12(2).

Shenton, A. K., \& Fitzgibbons, M. (2010). Making information literacy relevant. Library Review.

Sicilia, M.-A., García-Barriocanal, E., Sánchez-Alonso, S., Różewski, P., Kieruzel, M., Lipczyński, T., Royo, C., Uras, F., \& Hamill, C. (2018). Digital skills training in Higher Education: insights about the perceptions of different stakeholders. Proceedings of the Sixth International Conference on Technological Ecosystems for Enhancing Multiculturality,

Torras, M.-C., \& Saetre, T. (2016). Information literacy education: a process approach: professionalizing the pedagogical role of academic libraries. Chandos Publishing.

Tsai, M.-J., \& Tsai, C.-C. (2010). Junior high school students' Internet usage and selfefficacy: A re-examination of the gender gap. Computers \& Education, 54(4), 1182-1192.

Tuamsuk, K., \& Subramaniam, M. (2017). The current state and influential factors in the development of digital literacy in Thailand's higher education. Information and Learning Science.

Van Deursen, A. J., \& van Dijk, J. A. (2009). Improving digital skills for the use of online public information and services. Government Information Quarterly, 26(2), 333-340.

Williams, P., Fieldhouse, M., \& Rowlands, I. (2008). The Google generation: myths and realities about young people's digital information behaviour. Digital Consumers. Reshaping the Information Profession, Facet Publishing, London, 159-192.

Wingate, U., \& Tribble, C. (2012). The best of both worlds? Towards an English for Academic Purposes/Academic Literacies writing pedagogy. Studies in higher education, 37(4), 481-495.

Wong, K. K.-K. (2013). Partial least squares structural equation modeling (PLS-SEM) techniques using SmartPLS. Marketing Bulletin, 24(1), 1-32.

$\mathrm{Yi}, \mathrm{Z}$. (2007). International student perceptions of information needs and use. The Journal of Academic Librarianship, 33(6), 666-673. 